Evaluation of the influential relationship of the cost strategic analysis ...

Hussien abdelal salem

\title{
Evaluation of the influential relationship of the cost strategic analysis and its impact on the financial performance of the industrial companies with case study
}

\section{Hussien abdelal salem}

\section{Lecture in institute \& marketing Commerce $\&$ information system}

\section{Abstract :}

The objective of the research is to study and analyze the role of the tools of strategic analysis of cost in improving the financial performance of industrial establishments in general and applied to the pharmaceutical sector in Egypt in particular. In order to achieve this goal, two basic hypotheses were formulated. The first hypothesis is that there are no statistically significant differences between Respondents' responses to the importance of using strategic cost-analysis tools in cost management. "Second hypothesis: "There are no statistically significant differences between the role of using the tools of strategic analysis of cost and improve financial performance." To test these hypotheses, a set of appropriate statistical methods was used, as well as an analysis of some of the ratios and financial indicators of the company under study. The most important of which is: the development of traditional cost systems to maintain the current customer and attract new customers is very important for the continuation of business in the modern industrial environment, the adoption of industrial companies at the entrance of the strategic analysis of cost was the result of deficiencies in the systems Conventional costs In general, the strategic cost analysis 
Evaluation of the influential relationship of the cost strategic analysis ...

Hussien abdelal salem

tools provide the basis and practical principles to monitor the performance of the units of the industrial establishments, which is reflected in the financial performance of the establishments. Finally, the research recommended several recommendations, the most important of which are: the management of industrial establishments to adopt the application of methods of strategic analysis of costs in order to obtain accurate information For production, manufacturing and competition processes, which can be used to evaluate the actual performance of the establishment, the Egyptian industrial establishments must work to achieve the best level of the units produced through the design technology to preserve the quality.

Keywords : Tools for Strategic Cost Analysis - Improving financial performance

\section{Introduction :}

The business environment is characterized by a high degree of competitiveness, high customer expectations and increased demand for the right products and services at the right time and place with the lowest possible cost . In order to successfully compete in the business environment, establishments need to focus on increasing the accuracy of cost estimates and reaching the cost of the product to the minimum possible while maintaining the desired quality.

In this context, there are many internal and external environmental variables that have important effects on cost accounting systems and their information outputs, Which requires the need to develop these systems and adopt new 
Evaluation of the influential relationship of the cost strategic analysis ...

Hussien abdelal salem

approaches, methods and procedures, either in the field of measurement or analysis, In order to be able to meet the management needs of information and help them in managing cost strategies to take advantage of them in building strategies in line with their circumstances .

And with the urgent need to develop a cost accounting information system, Many industrial establishments have taken care to adopt the concept of strategic cost analysis using tools that enable them to achieve the strategic cost targets, The most important of which is to reduce costs to the minimum possible without compromising the quality of the product during the stages of its productive life cycle ( Daake.,et al , 2014,p236), Knowing that any decline in the cost of the product life cycle is reflected in a direct increase in the net profit by the same percentage or less according to the applicable rate of exchange with the stability of the other factors. Therefore, the low cost and rationalization of expenditure is one of the most important dimensions in improving the financial performance of the establishments .

Therefore, this research is intended to highlight the role of strategic analysis tools for cost in improving the financial performance of industrial establishments.

\section{$\underline{\text { Research Problem : }}$}

Financial performance for establishments is considered as a fundamental concept, It represents a reflective mirror for the activities of the establishments and their achievements during a certain period, Which means accurate judgment of the 
Evaluation of the influential relationship of the cost strategic analysis ...

Hussien abdelal salem

management of natural, material and financial resources available in the Organization, The financial performance of an enterprise is a measurement of the results achieved or expected in the light of previously defined criteria. The financial performance assessment is important for the management of establishments as it helps in determining the level of achievement of the objectives, determining the relative importance of the results and the resources used which allow judging the efficiency and the effectiveness .

It is worth mentioning that the strategic management of cost is one of the new approaches in the field of strategic direction, which contributes in providing the management with information that works on increasing the profits of establishments and support their long-term competitive positions, In addition to the information needed by the management of the establishments to take the appropriate decisions to support relations with customers and gain satisfaction while reducing costs at the same time.

With the increasing efforts of the establishments in recent times towards the increase of the level of accuracy of cost estimates, leading to the increase of the need for attention to cost and how to manage it , The conversion from the traditional cost management approach to the strategic cost management analysis to avoid many of the disadvantages of the traditional approach to cost analysis ( hekal ,2014,p3 ) . In addition, the last approach is a fundamental element in which the cost can be interpreted in an establishment when a competitive pricing strategy based on the cost advantage, This approach mainly takes the cost down to its 
Evaluation of the influential relationship of the cost strategic analysis ...

Hussien abdelal salem

initial competitive limits and contributes in building the ways in which establishments can achieve the strategic cost reduction .

In this context, the study of ( pettersson,2015p12; stein,2013.,pp50-63) Pointed out that more than 640 industrial establishments at the global level are trying hard to increase their level of cost accuracy in recent times. Which prompted the researcher to try to find a relationship between the use of tools of strategic analysis of cost and improve the financial performance in the establishments and based on the above the researcher tries hard to answer the following question :

1. What is the nature, concept and importance of strategic analysis of cost and what are its most important tools?

2. What is meant by financial performance of the establishments and its importance and factors affecting it?

3. Is there an effective relationship between the use of strategic analysis of cost and financial performance in establishments ?

4. What is the possibility of conducting an applied study (case study) on the role of strategic analysis tools for cost in improving the financial performance of enterprises?

\section{$\underline{\text { Research Objectives: }}$}

1. Presentation of the nature, concept and importance of strategic analysis of cost and its most important tools.

2. Knowing what is meant by the financial performance of the establishments, its importance and the factors affecting it. 
Evaluation of the influential relationship of the cost strategic analysis ...

Hussien abdelal salem

3. Statement of the relationship between the use of strategic analysis of cost and financial performance in establishments .

4. Conducting an applied study (case study) on the role of strategic analysis tools for cost in evaluating the financial performance of industrial establishments .

\section{$\underline{\text { Research Significance: }}$}

In light of the research problem, the importance of scientific and practical research is represented as following :

\section{Scientific Importance :}

The research gains its scientific importance as it considered as one of the research studies that deals with the role of the tools of strategic analysis of cost in improving the financial performance of the industrial establishments, especially in light of the challenges and changes facing the accounting systems and cost management in establishments in order to achieve outstanding financial performance .

\section{Practical Importance :}

The importance of practical research is due to the increasing interest of the establishments' managements towards improving their financial performance, which requires the search for new cost tools that can be used to manage the cost in the industrial establishments in general and the Egyptian industrial establishments in particular. A strategy that has an effective effect on improving the financial performance of the 
Evaluation of the influential relationship of the cost strategic analysis ...

Hussien abdelal salem

establishment under study in preparation for its dissemination to similar establishments.

\section{Research Methodology :}

The researcher relied on the use of the dual approach, using the inductive method in the theoretical aspect of the research, through reading the previous studies. The researcher followed the deductive approach through the work of the applied case study to determine the role of the tools of strategic analysis of cost in improving the financial performance of industrial establishments.

\section{Research Structure :}

For the purpose of achieving the research objectives, it will be planned and organized as follows :

Section One : Strategic Cost Analysis (Concept - Importance Key Tools)

Section Two : Presentation of the concept of financial performance of the establishments, its importance and factors affecting it .

Section Three : The effective relationship between the use of strategic analysis of cost and financial performance in establishments .

Section Four : Review the literature of the relevant study and derive the hypotheses .

Section Five : applied study ( case study ) on the role of strategic analysis tools for cost in improving the financial performance of industrial establishments . 
Evaluation of the influential relationship of the cost strategic analysis ...

Hussien abdelal salem

Results, recommendations and future research..

Section One : Strategic Cost Analysis (Concept - Importance - Key Tools).

\section{1/1 The Concept :}

The strategic cost analysis represents a series of successive and sequential stages which aim to study and analyze factors and changes affecting the direction and future of the establishment and determine the effects of these changes within the framework of the internal environment and the external environment and study the nature of internal relations and interaction between these changes. In this context the two study for (Elgnaby, 2014, p182; Akan.,et al ,2015, pp47- 49 ) have confirmed that The strategic cost analysis represents the first step of strategic management to monitor the environment of the establishment across two ways, The first is represented in : Current and future opportunities and threats, while the second is represented in : Strengths and weaknesses within the organization. Managers' purpose of analysis should be to identify multiple environments in which the establishment can operate, and the results of the analysis should enable the strengths of the establishment and its preparations to secure what needs to be done and enable it to see any future problems clearly .

The researcher believes that the strategic analysis of cost is the analysis of cost data that contribute to the development of plans which lead to a competitive advantage, Analysis of internal and external environment and cost factors, using a set of tools the most important of which is the analysis of the value chain, Cost 
Evaluation of the influential relationship of the cost strategic analysis ...

Hussien abdelal salem

analysis based on activity, as well as total quality and continuous improvement. The aim of this analysis is to obtain financial and non-financial data to formulate the strategy of the establishment.

\section{1/2 Objectives of The Strategic Cost Analysis :}

It was confirmed with the study of ( Elafery,2016 , p17 ; Cokins \& Cabusneanu 2015,pp7-11;Collin.,et al ,2015,p419 ) that The strategic analysis of cost seeks to achieve a set of objectives can be represented as following :

1. Provide information that helps to understand the causal relationship between the performance of activities and the factors that cause their cost, and to provide a better understanding of cost behavior, and rationalize the use of available resources. The analysis of costs from a strategic perspective through the integration of a range of methods of analysis represented in : Load value chain, cost-factor analysis, strategic position analysis. Which allow for different analyzes that are suit with the requirements of strategic cost management .

2. Help in creating better value for products which is reflected on customer satisfaction, And good allocation of establishment resources by providing information on the performance and costs of each activity, and identifying which activities generate greater value To which resources should be directed, as well as activities that add value, but are not performed efficiently, allowing the management of the establishment better opportunities to monitor, evaluate, improve its performance and improve its efficiency, As well as unnecessary activities that do not add value to the 
Evaluation of the influential relationship of the cost strategic analysis ...

Hussien abdelal salem

product to try to eliminate or reduce them, and thus support continuous improvement efforts, and create better value for customers .

3. Support the competitiveness of establishment in the short and long term, by providing information on cost reduction areas, Deficiencies and waste . help in managing cost not only within the organizational boundaries of the establishment, but beyond those limits to To include suppliers and customers across the value chain, as well as to analyze and provide external information about competitors .

\section{1/3 Stages of Applying Strategic Cost Analysis :}

The appropriate strategy for the establishment is determined in the light of the study and analysis of the internal environment and the external environment. Therefore, the implementation of the strategic cost analysis includes two phases, The first phase: Analysis of environmental conditions while the Second phase : Identify opportunities, risks and strengths and weaknesses In this context, a study was conducted ( Mansour ,2014, p106 ) these phases as following:

\section{The first phase: Analysis of environmental conditions which include :}

1. Analysis of the general environmental conditions surrounding the enterprise which are the economic conditions and the conditions of the technological environment, the conditions of the political and legal 
Evaluation of the influential relationship of the cost strategic analysis ...

Hussien abdelal salem

environment, and the conditions of the social and cultural environment .

2. Analysis specific or partial environmental conditions, which include analysis of the establishment, competition, marketing, suppliers and customers ( hisham Elslowatshy and yousef Bodola , 2010 )

\section{The Second phase : Identify opportunities, risks and strengths and weaknesses which include :}

In light of the identification, study, analysis and evaluation of the external and internal environment, the establishment can build a strategy that fits its circumstances and the previous analysis necessitates the availability of a set of methods and tools, most important is the compatibility between internal and external conditions. The steps of that stage can be presented in the following points as the study of ( Bekhet ,2013, p12 ) :

1. Identify the manifestations of power, the manifestations of strength the establishment have may be able to exploit the opportunities that result from changing environmental conditions or market conditions or behavior of customers.

2. Identification of weaknesses, Reflecting low resources and core competencies compared to competitors such as weak research and development programs, and weak production lines .

3. Identify opportunities, which relate to the positive conditions in the external environment of the institution such as increasing awareness of the society in terms of taste and the importance of maintaining health, and expected consumer demand for the new product . 
Evaluation of the influential relationship of the cost strategic analysis ...

Hussien abdelal salem

4. Identifying threats that reflect unfavorable conditions or obstacles to the present and future of the establishment .

\section{1/4 Tools for Strategic Cost Analysis :}

The adoption of the concept of strategic cost analysis leads to the transformation of establishment from the internal cost vision to external vision of what costs should be , In the sense of focusing on the strategic participation of information with customers and suppliers in addition to the areas of research and development with the emphasis on not sharing this information with other parties outside this relationship and that what (Ansari, et al., 2016.,pp56-60) study confirmed .

The implementation of the strategic cost analysis requires many tools that help product designers achieve the target cost of their products. The most important of these tools, according to the study of (Anderson \& Dekker, 2015.,p82 ) is :

- Value chain analysis.

- Cause of cost analysis.

- Analysis of the strategic position of cost.

- Disassembly analysis .

The researcher will address these tools in details :

\section{1/4/1 Value chain analysis :}

Value chains represent the cornerstone of creating lasting competitive advantage by providing financial and non-financial information on all activities of the establishment . Starting From product design to post-sale services, Which entails the establishment of an analysis and guidance of activities and 
Evaluation of the influential relationship of the cost strategic analysis ...

Hussien abdelal salem

resources to the citizen of value and then the target cost and excellence of the product to satisfy the customer ( Abd-elazeem , 2015 , p20 ).

The value chain is a systematic evaluation of all value chain activities with the aim of reducing costs, improving quality and meeting the needs of customers, thereby improving the financial performance of the enterprise.

In this context, a study of (Walters \& Rainbird, 2004, p 465 ) has been reached to that the analysis of the value chain affects the length of the product life cycle taking into account the total activities used in it and the extent to which each activity contributes to the creation of the total value of the product in order to exclude each activity to add to that value .

\section{1/4/2 Cause of Cost Analysis :}

Both (Valipour, et al., 2012, pp14-23; Akan,et al., 2015, pp 43-53) studies agreed that the cost drivers are the set of factors that are proportionately associated with the resource consumption of the activity, Thus providing a basis for explaining the behavior of the cost of the activity, which helps to achieve the accuracy and objectivity of cost measurement, on one side it contributes to the implementation of the strategy of cost leadership and on the other side it supports of the competitiveness of the establishment .

In this regards, (Cokins \& Cabusneanu, 2015, pp. 7-16) examined the cost factors according to the activity levels of the establishment and classified them into the following cost factors : 
Evaluation of the influential relationship of the cost strategic analysis ...

Hussien abdelal salem

- Operational cost drivers : Which are related to the activities performed at the unit level of the product, and thus reflect the number of units produced in relation to the cost of consumption of resource activity such as direct working hours.

- Procedural cost drivers : Which are related to the activities performed at the level of the production batch, such as the number of operating orders as a reason for the production scheduling activity .

- Structural cost factors : Which are related to the quality of units produced according to the characteristics of the product itself and its characteristics such as economies of scope, experience, technology, and degree of complexity .

- General cost drivers : Which are related to the activities that are performed to maintain the general production capacity of the establishment as a whole, such as the number of employees as a cause of the activity of administrative affairs, and the number of shifts as a reason for the activity of industrial security.

\section{1/4/3 Analysis of The Strategic Position of Cost :}

A cost strategy can be defined as the ability of the establishment to offer its products and services at the lowest cost compared to its competitors, As it aims to reduce the cost to a minimum without compromising the quality of the product. This cost analysis requires a strategic analysis to achieve competitive advantages in order to reduce the price of the product to reach the cost level that characterizes the establishment strategically in order to improve the financial performance of the establishment . 
Evaluation of the influential relationship of the cost strategic analysis ...

Hussien abdelal salem

In this context, the study of ( Akan, et. al., 2015,43-53; Atkinson, et. al., 2011., p. 351) agreed that there are three strategies that companies are seeking to achieve and are in the process of analyzing the strategic position of cost. These strategies are as follows:

A. Costing Leadership Strategy : It is the establishment's ability to produce at the lowest cost if compared to its competitors by improving productivity and eliminating activities that do not add value to the product and effective control over the cost elements, thus taking the price as a competitive advantage and can achieve value for the customer and gain his satisfaction .

B. Differentiate Strategy : This strategy includes a set of actions and activities undertaken by the establishment to provide products with unique characteristics and rare features of the product that are difficult to emulate from competitors, and are aimed at influencing customer attitudes and behavior to support the continuous competitive advantage of the establishment .

C. Focus Strategy : This strategy is based on selecting a specific sector of the market. The establishment does not deal with the market as a whole, but rather divides the market into a number of sectors and focuses on a specific part of the market .

\section{1/4/4 Disassembly Analysis :}

The study of ( Jermias, J., 2015,p13; Sandborn,2014, pp. 1021-1026 ) agreed that disassembly analysis means unpacking of competitors' product and determine its functionality and 
Evaluation of the influential relationship of the cost strategic analysis ...

Hussien abdelal salem

design method which Provide designers with an additional insight into the potential production processes and cost structure of the product to identify opportunities for improvement and to establish any comparative advantages of the product's competitive products, enabling the establishment to determine the target cost of the product components based on the study of competitor products .

At the end of this section, the researcher sees that the strategic analysis of cost is based on a set of tools that integrate with each other during the life cycle of the product in order to increase the efficiency of the financial performance of the establishment and identify the problems facing the implementation of planning budget .

Based on the above, the researcher in the next section will be exposed to the concept of financial performance and its importance and factors affecting it .

\section{Section Two : Presentation of The Concept of Financial Performance of The Establishments, Its Importance and Factors Affecting It :}

\section{1/2 The Concept :}

The concept of financial performance stems from the concept of financial function, where the financial function seeks to obtain a basis to improve the efficient use of funds and resources available within the enterprise and expresses the ability of the entity to generate profits over a certain period of time. Financial performance for establishment also represents a fundamental 
Evaluation of the influential relationship of the cost strategic analysis ...

Hussien abdelal salem

concept as it is a measure of results achieved or anticipated in the light of specific criteria in advance (Hassan, 2014 ,p55).

\section{2/2 The Importance of Evaluating Financial Performance :}

The importance of financial performance returns to the study of ( Boresh,2016,p155-167 ) to a set of objectives seek to analysis and study of financial performance which can be represented as following :

1. Follow-up and knowledge of the activity of the establishment and the nature of the surrounding economic and financial conditions.

2. Conduct analysis, comparison and interpretation of financial data for appropriate decision making as it highlights the following aspects :

a. Evaluate the profitability of the establishment: in order to maximize the value of the establishment and the wealth of the shareholders .

b. Estimate the liquidity of the establishment: to know the ability of the establishment to meet the obligations incurred.

c. Evaluate the activity of the establishment: to know how the establishment distributes its financial resources and invests them.

d. Assessing the indebtedness of the establishment (assesses the financial leverage): to determine the extent of the institution's dependence on loans.

e. Evaluation of the size of the establishment: to determine the extent of the establishment's growth and prosperity. 
Evaluation of the influential relationship of the cost strategic analysis ...

Hussien abdelal salem

f. Assessing the entity's dividends for profits: to know the entity's policy of distributing dividends.

\section{2/3 Factors Affecting Financial Performance :}

The financial performance assessment process is one of the key processes for the success and sustainability of an enterprise because of its ability to identify the difficulties facing the establishment, Which affect the performance of their work, identify the sources of these difficulties and analyze them and make appropriate decisions thereon, the study of ( Elshtrat , 2015 p517-557 ; Elkbesy ,2015,p 105-134) the factors affecting financial performance into :

2/3/1 Repayment Ability : reflects The ability of an establishment to repay its liabilities from loans and interests on the maturity date by comparing the loan charge with the expected cash flow of the company for the coming years. The company's good financial performance is affected by its ability to meet its obligations and the possibility of being exposed to bankruptcy .

2/3/2 Flexibility: It reflects the ability of an establishment to continue under changing circumstances (the ability of an entity to switch from one source of financing to another without a negative impact on the performance of the establishment).

2/3/3 Control : It is the ability of the entity to exercise control over the elements of capital by maintaining its administrative control over the establishment, resulting from its ability to maintain the shares of the old owners 
Evaluation of the influential relationship of the cost strategic analysis ...

Hussien abdelal salem

and avoid issuing new shares, so as not to lose part of its control and its preference for financing by borrowing.

2/3/4 Organizational Structure : The organizational structure means the container or frame in which all the variables related to the entity and its business interact. It specifies the powers, communications, responsibility and methods of exchanging information, The organizational structure affects the performance of the establishment by assisting in the successful implementation of the plans by identifying the responsibilities, actions and activities to be undertaken and allocating the necessary resources to facilitate the decision making process.

2/3/5 Technology : As technology is one of the most important challenges facing the establishment at present, the establishment must determine the type of technology appropriate to the nature of its work and in line with its objectives, adapt and absorb them in order to match the technology and performance, which leads to increased profits .

2/3/6 Customer Satisfaction : The interest of the establishment in customer satisfaction, through the provision of after-sales services leads to attract new customers, which in turn leads to increased sales of the establishment, and thus increase profits and improve financial performance, and lead to a decline in customer turnover, Thus reducing the cost of replacing them. 
Evaluation of the influential relationship of the cost strategic analysis ...

Hussien abdelal salem

The researcher considers that the process of measuring financial performance is the collection and analysis of information about the actual performance of the activity and provide feedback and help the establishment to identify the weaknesses and strength and improve performance, and therefore The performance measures used must meet certain conditions the most important of which are :

1. Ability to meet the requirements of stakeholders and maximize their satisfaction.

2. Ability to develop the strategy of the establishment and focus on the vital areas and improve the competitive position of the company .

3. help to understand the causal relations between different measures and rapid response to the variables.

After reviewing the concept of financial performance, its importance and the factors influencing it, the researcher will present the influential relationship between the use of strategic analysis tools for cost and their ability to improve the financial performance of the establishments.

Section Three : The Effective Relationship Between The Use of Strategic Analysis of Cost and Financial Performance In Establishments :

The strategic cost analysis is one of the new approaches in the field of strategic direction, which contributes in providing the management with information that will increase the profits of enterprises and support their long-term competitive positions , It is worth mentioning that the strategic analysis of the cost is 
Evaluation of the influential relationship of the cost strategic analysis ...

Hussien abdelal salem

useful in the required analysis in the dissemination of the quality function, which helps the establishment in determining the relative values of the characteristics of the products, where the value of the characteristics of the product to the client related to what the customer wants to pay and helps establishment to establish an estimate of the average costs of these characteristics, According to the characteristics of the product ( Debusk,G.and Debusk,C.,2014 .,p35 ) .

And from the effectiveness of strategic analysis of cost in the analysis of customer profitability (Mahmoud and Mohamed,2014,p15) Business establishments benefit from the information they provide in making strategic decisions such as pricing products and identifying the products to be sold, as this analysis connects several important variables that are both the desires and expectations of consumers, Competitive factors, available facilities, and management strategies in an attempt to balance the objectives of the establishment with the objectives of its customers while maximizing the total value of the establishment ( Saleh, 2014,p66 ). Provided that the costs of the product are managed so as to avoid any deviation from the required accuracy, Since the cost of the product is understated under Costing, The entity incurs actual losses that may result in the erosion of its capital, especially when the selling price is lower than the actual cost, in determining the cost of the product over costing, the enterprise is liable to loss as a result of decreasing market share, especially when the selling price is excessive (Horngren et al.,2015,pp55-75) Which is reflected in the financial performance of the establishment . 
Evaluation of the influential relationship of the cost strategic analysis ...

Hussien abdelal salem

The researcher believes that the strategic analysis of cost helps to develop alternative budgets to implement the optional costs, and thus the management can choose the budget that fit the potential and resources of the establishment, In addition to the strategic analysis of cost with the philosophy of cost target where the focus is on the target cost of the levels of achievement of each of the characteristics of the product in order to achieve the profits target, Also, when planning and designing the product, the target cost is considered to help control the product specifications and the levels of completion of each characteristic. This is not limited to the design stage, but extends to all stages during the product life cycle .

The researcher emphasizes that the strategic analysis of cost increases the market share of the company, providing greater consumer purchasing flexibility and increasing the chances of marketing the product, which improves the competitive financial performance of the business establishment, Where improving the levels of achievement and meeting the needs and desires of customers and consumers that meet the specifications of the product, and necessarily in the direction of improving the performance of the establishment as a whole .

The researcher agreed with the study of ( Abd ElReda, 2016, p106 ) that a strategic cost analysis enables an estimated cost of the product when many products are produced in the value stream, each of which consumes resources at different rates . Thus providing a better basis for determining conversion rates. It also helps accountants to know whether an entity can use lean accounting to account for product costs . 
Evaluation of the influential relationship of the cost strategic analysis ...

Hussien abdelal salem

After reviewing the relation of the strategic analysis of cost to the financial performance of the establishments, the researcher in the next section will take up and review the literature of the relevant study and derive the hypotheses.

\section{Section Four : Review The Literature of The Relevant Study and Derive The Hypotheses :}

The study of ( Slagmulder, 2015.,pp42-63) reached to demonstrate the importance of cost management in the current competition environment, with the need to shift from cost management to reduce strategic cost management, the application of cost management tools that enable the promotion of competitive position while reducing cost at the same time, The study distinguishes between cost management outside the regulatory boundaries of the establishment and costs which are under control such as procurement and distribution costs and costs not under the control of the establishment such as supplier manufacturing costs where collaboration and coordination between supply chain members is required to reduce cost . The study concluded that cost management programs outside the organizational boundaries of the establishment should extend to all members of the supply chain .

While the study of ( Foda,2007, p187-253 ) take concern of presenting and analyzing the problem of reducing the costs of various activities, Through the concept of analysis of the value chain of the establishment, and the study stressed the need for two tools of cost management are: the method of cost target, and strategic cost analysis to build an integrated framework to reduce the costs of different activities. The study was based on an 
Evaluation of the influential relationship of the cost strategic analysis ...

Hussien abdelal salem

exploratory study to determine the feasibility of the degree of integration between these two tools to build an integrated framework in order to reduce the costs of various activities through the concept of value chain analysis for some Egyptian industrial companies, . The study concluded that the target cost method can be determined using some cost-cutting tools such as value engineering, cost tables as one of the most relevant tools to implement the target cost method in Japanese companies .

In this context, a study of ( Bagaga,2014,p101-146 ) was conducted that achieving the main objective is to address the treatment of the problems of strategic analysis of cost, and to know the feasibility of application in the Saudi industrial companies, The study also focused on determining the stages and tools of the strategic analysis of the cost and the levels of its success. The study adopted an applied study that included a survey list for the industrial companies in the cement sector with analysis of the study data. The study concluded that the implementation of the strategic cost analysis required many tools to achieve the target cost, the most important of which is value engineering, cost tables, disassembly analysis and continuous cost improvement. The study recommended that cost accountants in industrial establishments should recognize the necessity of applying the concept of strategic cost analysis .

The two studies of ( Nasf , 2013, p44 ; Pettersson,; 2015.,pp94102 ) that To assessing the effectiveness of applying cost reduction approaches to determine their efficiency in achieving competitive cost to meet the modern industrial and economic environment variables, The results of the two studies have 
Evaluation of the influential relationship of the cost strategic analysis ...

Hussien abdelal salem

shown that cost accounting and financial managers are aware of the impact of intense competition on the use of cost reduction methods in their traditional form, And the two studies recommended the need to adopt modern methods of cost reduction to keep abreast of developments in the modern industrial environment to achieve real and continuous reduction of cost, which leads to more efficient and effective methods applied by the establishment to reduce the cost .

The study of (sayed ,2015, p133) achieved to evaluate the effectiveness of the integration of strategic cost management tools such as activity-based cost input, target cost, Value chain analysis methods and strategic performance evaluation methods such as Balanced performance measures, benchmarking method in providing appropriate information for strategic management of the establishment, improving its performance and supporting its competitive position. The study recommended the application of the proposed model for the integration of the methods of strategic management accounting in the Egyptian industrial organizations to help strengthen their competitive advantage .

The study of (Ali, 2015, p83) has taken a A sample of the accountants, directors, heads of cost departments and heads of financial sectors in a number of industrial companies working in different sectors and sectors in Alexandria, Borg El Arab and Amreya area on the extent to which these companies apply the concept of cost management strategy. The study found that the majority of the companies in the study apply the concept of strategic management of cost in part and incomplete, and the results showed that the majority of companies rely on one or two 
Evaluation of the influential relationship of the cost strategic analysis ...

Hussien abdelal salem

methods or at most three methods of cost management methods are also partially applied. The study recommended the dissemination of theoretical and practical thought to the concept of strategic cost management based on clear methodological steps between the Egyptian industrial companies in order to be able to cope with the rapid and successive changes in the contemporary business environment and to be able to cope with the waves of intense competition.

\section{Commenting on previous studies and presenting the research gap and deriving the hypotheses :}

The previous studies dealt with the issue of strategic costs and the extent of their use in the decision-making process, and the factors affecting their implementation and the importance of their implementation. Despite the various aspects dealt with in previous studies, this study is an attempt to present the role of the tools of strategic analysis of cost in improving the financial performance of business establishments .

The researcher believes that despite the valuable contributions added by previous studies in the field of strategic analysis of cost, these studies - within the limits of the researcher - did not address the role that can be performed by the strategic analysis of cost in improving the financial performance of industrial establishments, especially in the industrial establishments working in Egypt .

Based on the above, the following hypotheses can be derived : 
Evaluation of the influential relationship of the cost strategic analysis ...

Hussien abdelal salem

The first hypothesis : "There are no statistically significant differences between respondents' responses to the importance of using cost analysis tools in cost management ".

The second hypothesis : "There are no statistically significant differences between the role of using the tools of strategic analysis of cost and improving financial performance ".

\section{Section Five : Applied Study ( Case Study ) on The Role of Strategic Analysis Tools For Cost In Improving The Financial Performance of Industrial Establishments :}

The applied research study aims primarily at testing the research hypotheses by applying to the industrial companies operating in Egypt, especially one of the pharmaceutical companies registered in the Egyptian Stock Exchange Which depends on the cost of strategic analysis tools to reach their cost estimates. Based on the desire of the management of the establishment not to disclose its actual cost data or information that may affect its competitive position, The researcher reserves the right to declare the name of the commercial establishment due to the sharp competition in the labor market of the companies to which the establishment belongs .

\section{5/1 A Brief About The Establishment and Its Main Activities:}

The establishment was established in 1980 and is a public company listed on the Egyptian Stock Exchange since September 1995. The establishment operates in the pharmaceutical, biotechnology and life sciences sector with a focus on medicines The company has branches and subsidiaries operating all over Egypt. The establishment produces about 800 million units 
Evaluation of the influential relationship of the cost strategic analysis ...

Hussien abdelal salem

annually. It also owns shares in the global pharmaceutical production facility in the major Gulf countries, The company has research and development laboratories, manufactures more than 300 prescription and medicines and covers more than 23 treatment groups. The company accounts for a large share of Egypt's total pharmaceutical exports , The company constantly develops its operational performance and product development to become one of the most important companies in the pharmaceutical sector in Egypt due to the inflated volume of its investments in recent times as it applies the latest production systems and depends on the entrance of strategic management accounting and analysis of value chains to the accuracy of the cost indicators of its products .

\section{5/2 the Research hypotheses :}

In order to test the relationship between the search variables, the research hypotheses were formulated as follows:

The first hypothesis : "There are no statistically significant differences between respondents' responses to the importance of using cost analysis tools in cost management ".

The second hypothesis : "There are no statistically significant differences between the role of using the tools of strategic analysis of cost and improving financial performance ".

\section{3/5 Measuring Variables :}

A. The first independent variable of the first hypothesis : This variable was measured by asking the inquisitors about the 
Evaluation of the influential relationship of the cost strategic analysis ...

Hussien abdelal salem

effectiveness of the use of cost analysis tools in the cost management of the establishment under study .

\section{B. The second independent variable of the second hypothesis}

: This variable was measured by asking the inquisitors about the role of using the Tools for strategic cost analysis in improving financial performance.

\section{The dependent variable (financial performance of the} establishment under study): through depending on the information published in the Company's annual financial statements (beginning on 1/1 and ending on 31/12 of each year) and approved by the external auditor to calculate the following financial indicators :

1. Ratio of total profit: This ratio measures the extent to which an establishment can achieve the greatest possible profit by controlling production costs (productive efficiency), Which is one of the main reasons for using the tools of strategic analysis of cost, and was calculated by dividing the total profit on net sales.

2. Net Profit Ratio: This ratio indicates the contribution of each of the sales to the net profit of the company and is calculated by dividing the net profit on the net sales.

3. Rate of return on assets: This ratio represents the ability and efficiency of the management of an establishment to invest all its assets in generating profits for the establishment, calculated by dividing the net profit on the total funds invested. 
Evaluation of the influential relationship of the cost strategic analysis ...

Hussien abdelal salem

4. Rate of Return on Equity (ROE): It measures the return that owners earn from investing their money in an establishment and is calculated by dividing net profit on average equity .

\section{4/5 Methods of Collecting Study Data :}

The study mainly relied on the method of interviews with officials of financial departments, information technology, marketing and sales, suppliers and costs of the establishment under study, The survey list included three sections. The first section focused on the personal data of the participants. The second section included two main questions for the research. The first question included seven terms to identify the effectiveness of the use of cost analysis tools in cost management, and the second question included nine statements on the role of the use of strategic analysis tools for cost in improving financial performance. The researcher relied on the fifth Lycart scale to measure the response to each of the research questions

The second part of the applied study was based mainly on the analysis of the financial statements of the establishment under study, which were obtained through the annual disclosure file for the lists and reports published on the website of the establishment or the Egyptian Stock Exchange. The analysis period is seven years from 2011 to 2017.

\section{4/5 Statistical Methods Used :}

The researcher relied on 48 valid forms of analysis with a response rate of $87.5 \%$, where 55 forms were distributed. SPSS 
Evaluation of the influential relationship of the cost strategic analysis ...

Hussien abdelal salem

(version 22) was used to conduct statistical analysis using the following statistical methods :

\section{4/5/1 Test the validity and stability of the research questions:}

The following table shows that the alpha coefficient for all the list items (16 words) was $89.9 \%$, indicating the validity and stability of the tool used. The Alpha Kronbach coefficient When over $80 \%$ is considered an indicator of the quality of the tool used to collect the data .

\section{Table 5/1:}

\section{The results of the Cronbach Alpha test for honesty and consistency data collection tool}

\begin{tabular}{|c|c|}
\hline No.of Items & Cronbach's Alpha \\
\hline 16 & 0.899 \\
\hline
\end{tabular}

5/4/2 Results of Descriptive Statistics of Answers of first Question:

The objective of this question is to identify the effectiveness of the use of cost analysis tools in the cost management of the establishment under study, using the descriptive statistical measures - the arithmetical mean and the standard deviation these variables are arranged on the basis of their relative importance according to the mean and standard deviations, as follows: 
Evaluation of the influential relationship of the cost strategic analysis ...

Hussien abdelal salem

\begin{tabular}{|c|c|c|c|c|c|c|}
\hline No. & Questionnaire sectors & Min & $\operatorname{Max}$ & $\begin{array}{c}\text { Arithmetical } \\
\text { mean }\end{array}$ & $\begin{array}{l}\text { Standard } \\
\text { deviation }\end{array}$ & Ranking \\
\hline 1 & $\begin{array}{l}\text { Strengthening complementary } \\
\text { relationships between cost management } \\
\text { tools leads to cost leadership }\end{array}$ & 2 & 5 & 4.06 & 0.817 & Second \\
\hline 2 & $\begin{array}{l}\text { Providing the product at a lower cost } \\
\text { than competitors achieves cost } \\
\text { leadership }\end{array}$ & 2 & 5 & 3.67 & 1.13 & Fourth \\
\hline 3 & $\begin{array}{l}\text { Providing a better value for the product } \\
\text { at a cost equal to the cost of } \\
\text { competitors achieves } \\
\text { excellence }\end{array}$ & 2 & 5 & 3.69 & 1.13 & Third \\
\hline 4 & $\begin{array}{l}\text { Application of total } \\
\text { management }(\mathrm{TQM}) \text { from a strategic } \\
\text { cost perspective can control the real } \\
\text { cost of the product and achieve } \\
\text { customer satisfaction }\end{array}$ & 2 & 5 & 4.07 & 0.926 & First \\
\hline 5 & $\begin{array}{l}\text { Depending of the establishment on cost } \\
\text { management strategies through the } \\
\text { value chain satisfies customer } \\
\text { satisfaction }\end{array}$ & 2 & 5 & 3.56 & 0.942 & Second \\
\hline 6 & $\begin{array}{l}\text { Adopt a product differentiation strategy } \\
\text { that delivers better value to the supply } \\
\text { chain }\end{array}$ & 1 & 5 & 3.66 & 1.07 & First \\
\hline 7 & $\begin{array}{l}\text { Adopting a focus strategy on a specific } \\
\text { group of customers leads to improved } \\
\text { quality and customer satisfaction }\end{array}$ & 1 & 5 & 3.11 & 0.844 & Third \\
\hline
\end{tabular}

As can be seen from Table (5/2), the categories of respondents strongly agree that the application of total quality management (TQM) from a strategic cost perspective enables the control of 
Evaluation of the influential relationship of the cost strategic analysis ...

Hussien abdelal salem

the real cost of the product and the satisfaction of the customer, as this will reduce the cost of the product life cycle, The mean of the sample of the study sample for this item was (4.07) . Therefore, this item is very important, and ranked first from the point of view of the views of the groups surveyed in the cost management of the establishment . And comes in second place from the point of view of the views of the surveyed groups that work to strengthen the complementary and cooperative relations between the tools of cost management leads to excellence and leadership in the cost of the product, The mean of the sample of the study sample for this item was (4.06). Therefore, this item is very important, While the work is to provide a better value for the product at a cost equal to the cost of competitors in third place from the point of view of the surveyed groups with an average of (3.69), And therefore this item is important, while comes in fourth place to provide the establishment for the final product at a cost less than competitors achieve cost leadership, an average of (3.67), and this item is also important .

in terms of competitive strategies preferred or followed by the establishment, the strategy of distinguishing the product provided by the establishment, which distinguishes it from other products in the market, ranked first in the competitive strategies where the mean of the opinions of the surveyed groups for this item (3.66), While the cost management strategy through the value chain ranked second, where the mean of the opinions of the surveyed groups for this item (3.56), and the strategy to focus on a particular group of customers in the last rank with an average of the views of the respondents (3.11). 
Evaluation of the influential relationship of the cost strategic analysis ...

Hussien abdelal salem

\section{5/4/3 The Descriptive Statistical Results of The Answers to The Second Question :}

The vocabulary of this question focused on the elements of the success of the cost system applied to the establishment under study, where the vocabulary included six elements were the relative importance of its effectiveness in the establishment as follows :

\begin{tabular}{|c|c|c|c|c|c|c|}
\hline No. & Questionnaire sectors & Min & Max & $\begin{array}{c}\text { Arithmetical } \\
\text { mean }\end{array}$ & $\begin{array}{l}\text { Standard } \\
\text { deviation }\end{array}$ & Ranking \\
\hline 1 & $\begin{array}{lrr}\text { Strategic } & \text { cost } & \text { analysis } \\
\text { provides a high level of } \\
\text { financial } & \text { information } \\
\text { quality. } & \end{array}$ & 2 & 5 & 3.83 & 1.02 & First \\
\hline 2 & $\begin{array}{l}\text { Strategic cost analysis } \\
\text { improves financial decision } \\
\text { making. }\end{array}$ & 2 & 5 & 3.78 & 0.908 & Second \\
\hline 3 & $\begin{array}{lrr}\text { Strategic } & \text { cost } & \text { analysis } \\
\text { contributes to } & \text { reducing } \\
\text { inventory and increasing } \\
\text { turnover }\end{array}$ & 2 & 5 & 3.70 & 1.08 & Fifth \\
\hline 4 & $\begin{array}{l}\text { Strategic cost analysis } \\
\text { reduces total costs. }\end{array}$ & 1 & 5 & 3.58 & 0.778 & Eighth \\
\hline 5 & $\begin{array}{llr}\text { Strategic } & \text { cost } & \text { analysis } \\
\text { increases } & \text { return } & \text { on } \\
\text { investment. } & & \\
\end{array}$ & 1 & 5 & 3.28 & 0.877 & Ninth \\
\hline 6 & $\begin{array}{l}\text { The strategic cost analysis } \\
\text { contributes to growth in } \\
\text { sales volume and increased } \\
\text { market share. }\end{array}$ & 2 & 5 & 3.66 & 0.908 & Sixth \\
\hline 7 & $\begin{array}{l}\text { Strategic cost analysis } \\
\text { improves the company's } \\
\text { competitive position }\end{array}$ & 2 & 5 & 3.77 & 0.902 & Third \\
\hline
\end{tabular}

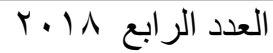

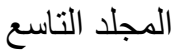


Evaluation of the influential relationship of the cost strategic analysis ...

Hussien abdelal salem

\begin{tabular}{|c|l|c|c|c|c|c|}
\hline $\mathbf{8}$ & $\begin{array}{l}\text { Strategic cost analysis } \\
\text { increases profitability. }\end{array}$ & 2 & 5 & 3.62 & 0.797 & Seventh \\
\hline $\mathbf{9}$ & $\begin{array}{l}\text { Strategic cost analysis } \\
\text { contributes in improving } \\
\text { financial measurements . }\end{array}$ & 2 & 5 & 3.72 & 0.911 & Fourth \\
\hline
\end{tabular}

As can be seen from Table (5/3), the categories of respondents strongly agree that the strategic cost analysis provides a high level of quality of financial information, The mean of the sample of the study sample for this item was 3.83 , so this item is very important. The first place in the opinion of the surveyed groups and second in the opinion of the surveyed groups is that the strategic analysis of the cost will improve the decision making process and The mean of the sample of the study for this item was equal (3.78). Therefore, this item is very important, And comes in the third position, the strategic analysis of the cost to improve the competitive position of the company with mean of (3.77), In the fourth place, the strategic cost analysis contributes to the improvement of the financial measures with a mean of (3.72) . The strategic analysis of the cost involved in reducing the inventory and increasing the rate of its circulation contributed to the fifth rank with a mean of (3.70), And based on the previous results it is clear that the five terms mentioned represent the most important variables that indicate the financial performance of the company. The strategic cost analysis contributes to the growth in sales volume and increase the market share of the company in sixth place with a relatively low mean of (3.66), And the phrase "strategic cost analysis" was used to increase profitability in the seventh rank with a mean of (3.62). And the term strategic cost analysis has been used to reduce the overall cost of the eighth 
Evaluation of the influential relationship of the cost strategic analysis ...

Hussien abdelal salem

rank by a mean of (3.58). In the end, the term strategic cost analysis was used to increase the rate of return on the ninth position with a mean of (3.28).

\section{5/4/5 Data Analysis and Testing of Study Hypotheses :}

5/4/5/1 : Presentation and discussion of the results of the first hypothesis: "There are no statistically significant differences between respondents' responses to the importance of using cost analysis tools in cost management ". To verify the validity of the hypothesis, the simple linear regression method used in the formulation of the outputs of the statistical program will be used according to the following table :

\section{Table ( 5/4 )}

Results of simple linear regression analysis to measure the relationship between the importance of using strategic cost analysis tools and cost management

\begin{tabular}{|c|c|c|c|c|}
\hline & $\begin{array}{c}\text { Regression } \\
\text { coefficients }\end{array}$ & Test (t) & $\begin{array}{c}\text { Probability } \\
\text { Value (sig) }\end{array}$ & Explanation \\
\hline $\mathrm{B}^{\wedge} 0$ & 1.504 & 7.204 & 0.00 & Significant \\
\hline $\begin{array}{c}\text { Correlation } \\
\text { coefficient (R) }\end{array}$ & 0.73 & & \\
\hline $\begin{array}{c}\text { The coefficient } \\
\text { of determination } \\
(\mathrm{R} 2)\end{array}$ & 0.53 & & \\
\hline Test (F) & 135.788 & \multicolumn{2}{|l}{} \\
\hline
\end{tabular}


Evaluation of the influential relationship of the cost strategic analysis ...

Hussien abdelal salem

1. The results of the evaluation showed a strong correlation between the importance of the use of the tools of strategic cost analysis and cost management, with the value of the coefficient of determination (R2) (0.53). This value indicates that the use of strategic cost tools contributes with $(53 \%)$ in cost management .

2. The simple regression model is significant, where the value of test $(\mathrm{F})(135.788)$, which is a function of the level of significance $(0.000)$.

Which means rejection of the first imposition and which eliminates " There are no statistically significant differences between respondents' responses to the importance of using cost analysis tools in cost management " And acceptance of alternative hypothesis .

5/4/4/2 Presentation and discussion of the results of the second hypothesis: "There are no statistically significant differences between the role of using the tools of strategic analysis of cost and improving financial performance " and to verify the validity of the hypothesis, the simple linear regression method used to formulate the outputs of the statistical program will be used according to the following table: 
Evaluation of the influential relationship of the cost strategic analysis ...

Hussien abdelal salem

\section{Table (5/5)}

Results of simple linear regression analysis to measure the relationship between the use of strategic analysis tools for cost and improve financial performance

\begin{tabular}{|c|c|c|c|c|}
\hline & $\begin{array}{c}\text { Regression } \\
\text { coefficients }\end{array}$ & Test (t) & $\begin{array}{c}\text { Probability } \\
\text { Value (sig) }\end{array}$ & Explanation \\
\hline $\mathrm{B}^{\wedge} 0$ & 1.624 & 7.601 & 0.00 & Significant \\
\hline $\begin{array}{c}\text { Correlation } \\
\text { coefficient (R) }\end{array}$ & 0.74 & & \\
\hline $\begin{array}{c}\text { The coefficient } \\
\text { of determination } \\
(\mathrm{R} 2)\end{array}$ & 0.55 & & \\
\hline $\begin{array}{c}\text { Test (F) } \\
\text { Tent }\end{array}$ & 138.999 & & \\
\hline
\end{tabular}

1. The results of the evaluation showed a strong correlation between the use of strategic analysis tools for cost and improving financial performance. Where the value of the coefficient of determination (R2) (0.55) . This value indicates that the use of strategic cost analysis tools contributes with $(55 \%)$ to improve the financial performance of the company.

2. The simple regression model is significant, with the value of test $(\mathrm{F})(138.999)$, which is a function of the mean level (0.000) .

Which means rejection of the second hypothesis, which eliminates " There are no statistically significant differences

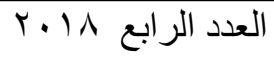

المجلد التاسع 
Evaluation of the influential relationship of the cost strategic analysis ...

Hussien abdelal salem

between respondents' responses to the importance of using cost analysis tools in cost management " And acceptance of alternative hypothesis .

\section{5/5 Analysis of Financial Statements :}

In order to determine the effect of the cost system applied in the establishment under study, an analysis of a set of actual financial indicators was carried out according to the published financial statements for the period from 2011 to 2017 to determine the improvement or deterioration in each of the financial indicators studied in the study. To study and test the validity of their hypotheses in practice. Microsoft Office (Excel) has relied on the following results :

\section{Table (5/6)}

\section{The most important financial performance indicators of the company under study from 2011 to 2017}

(numbers are rounded to thousands of Egyptian pounds)

\begin{tabular}{|l|c|c|c|c|c|c|c|}
\hline & $\mathbf{2 0 1 1}$ & $\mathbf{2 0 1 2}$ & $\mathbf{2 0 1 3}$ & $\mathbf{2 0 1 4}$ & $\mathbf{2 0 1 5}$ & $\mathbf{2 0 1 6}$ & $\mathbf{2 0 1 7}$ \\
\hline 1. & 2073611832 & 2223188372 & 2288184381 & 2337240403 & 2428881300 & 2477353238 & 2708934976 \\
\hline total assets & 1443060336 & 1490208478 & 1527895236 & 1574915453 & 1895231183 & 1659875860 & 2128864217 \\
\hline Owner's equity & 1100493624 & 1161600474 & 1252082324 & 1337129859 & 1553023983 & 1668045835 & 1937071163 \\
\hline Activity Revenue & & & & & & & \\
\hline Total profit & 436295047 & 441477475 & 430362589 & 422054925 & 495412449 & 521782185 & 719093784 \\
\hline
\end{tabular}


Evaluation of the influential relationship of the cost strategic analysis ...

Hussien abdelal salem

\begin{tabular}{|l|c|c|c|c|c|c|c|}
\hline 5. Net profit & 325948403 & 317158808 & 306010891 & 312593155 & 320315730 & 370821177 & 468988357 \\
\hline $\begin{array}{l}\text { 6. Ratio of total } \\
\text { profit = (4/3) }\end{array}$ & $\% 39$ & $\% 38$ & $\% 34$ & $\% 31$ & $\% 32$ & $\% 31$ & $\% 37$ \\
\hline $\begin{array}{l}\text { 7. Net profit ratio = } \\
\text { (3/5) }\end{array}$ & $\% 2.9$ & $\% 2.7$ & $\% 2.4$ & $\% 2.3$ & $\% 2$ & $\% 2.2$ & $\% 2.4$ \\
\hline $\begin{array}{l}\text { 8. Return on Assets }= \\
(1 / 5)\end{array}$ & $\% 1.5$ & $\% 1.4$ & $\% 1.3$ & $\% 1.3$ & $\% 1.3$ & $\% 1.4$ & $\% 1.7$ \\
\hline $\begin{array}{l}\text { 9. Return on } \\
\text { Ownership = (2/5) }\end{array}$ & $\% 2.2$ & $\% 2.1$ & $\% 2$ & $\% 1.9$ & $\% 1.6$ & $\% 2.2$ & $\% 2.2$ \\
\hline
\end{tabular}

The previous table (5/6) shows the following main results regarding the financial position of the establishment under study:

1 - Increasing the funds invested for the company (total assets) during the years of analysis, the researcher believes that this increase in investments can be attributed to the significant increase in the activities of the company and the number of products.

2 - The growth of property rights during the study period on a regular basis and semi-fixed, and this is what the management of the establishment sought and disclosed since the inception of the establishment.

3 - Increasing the revenue of the activity of the establishment significantly during the years of analysis on a regular basis, and the researcher believes that this increase is due to financial stability within the establishment because of the establishment's successful management policies and cost strategies that correspond to the nature of the competition experienced by the establishment .

4- As for the company's total profit, we find that it is increasingly moving except in 2013 and 2014, where the company passed 
Evaluation of the influential relationship of the cost strategic analysis ...

Hussien abdelal salem

some of the economic conditions that followed the revolution of January, but the researcher finds that the establishment from 2015 until 2017 and is moving steadily to multiple successes, especially under strategies Successful costs and their impact on the financial performance of the establishment .

5- In terms of net profit, the decrease is evident in the first years of the analysis, but between 2014 and 2016 things started to improve. The explanation is due to the increase in indirect costs in general (depreciation of fixed assets) and administrative expenses in particular Increase security and guard personnel for all establishment sites.

6- With regard to the rate of return on assets, we believe that there is relative semi-stability in this return, and the researcher believes that this is a positive indicator in light of the severe competition experienced by the market of the pharmaceutical industry in Egypt.

7- Fluctuation rate of return on equity between cycles of increase and decline, and the researcher believes that the relative decline of this return (return on equity, which did not exceed 2.2\% during the study period ) . Although the establishment achieved high rates for the total profit, due to the high fixed charges of the establishment .

From the previous analysis, the researcher believes that the positive financial situation of the establishment under study can be attributed to the adoption of the company to the entrance of the strategic analysis of cost and the adoption of successful administrative and financial policies. 
Evaluation of the influential relationship of the cost strategic analysis ...

Hussien abdelal salem

The results, recommendation and future researches :

\section{First : the results :}

The study examined the role of the tools of strategic analysis of cost in improving the financial performance of industrial establishments in general and applied to the pharmaceutical sector in particular. After examining the results of many theoretical and practical studies, the research concluded the following results:

1- The development of traditional cost systems to maintain the current customer and attract new customers has become indispensable for the continuation of business in the modern industrial environment.

2- The adoption of industrial companies on the entrance of the strategic analysis of cost was the result of deficiencies in the traditional cost systems in general.

3- The tools of strategic analysis of costs provide the basis and practical principles to monitor the performance of units of industrial establishment .

4- The value chain analysis method examines cost-effective processes and activities during the product lifecycle in order to reduce them .

5- The evaluation of the performance of the establishment through the tools of strategic analysis of costs allows to identify the problems experienced by the implementation of the planning budget for an establishment .

6- The results of the study and analysis of the financial situation of one of the Egyptian construction establishment confirmed the positive integrated approach between the 
Evaluation of the influential relationship of the cost strategic analysis ...

Hussien abdelal salem

entrance of the costs of activities and the introduction of the cost of specifications on the financial situation .

\section{Second : The recommendations :}

In light of the findings of the research, the researcher recommends the following recommendations:

1- The need to update the cost systems applied in industrial establishments in line with modern environmental changes.

2- The management of industrial establishments should adopt the application of the methods of strategic cost analysis in order to obtain accurate information on the production, processing and competition processes, which can be used to evaluate the actual performance of the establishment.

3- Egyptian industrial establishments should work to achieve the best level of units produced through the design technology to maintain the overall quality.

4- The management of Egyptian industrial establishment should adopt the method of analysis of the value chain so as to be able to pay attention to activities that add value to the product.

5- Develop awareness of employees of Egyptian industrial establishments to take into account the flexibility of production and cost to comply with the wishes of customers changing.

6- Directing attention to further research in the field of strategic analysis of cost. 
Evaluation of the influential relationship of the cost strategic analysis ...

Hussien abdelal salem

\section{Third : Future Research Areas :}

1- Study the effect of the combination and integration between the cost and specifications and activities on the financial performance indicators applied to the industrial establishments.

2- An integrated approach to strategic cost management to support the competitiveness of service sector companies listed on the Egyptian Stock Exchange .

\section{References :}

\section{First : Arabic references :}

1. Bagaga , Salem Saeed ( 2014 ), " Strategic analysis of costs and feasibility of application - Applied study on cement companies in Saudi Arabia ", Journal of Business Research, Faculty of Commerce, Zagazig University, First and Second Issue, Volume Thirty-one, January and July .

2. Bekhet, Youseef Abd El Baky ( 2013 ), " Strategic analysis of costs to strengthen the competitive advantage of the establishment applied theory study", unpublished doctoral thesis, Faculty of Commerce, Helwan University .

3. Boresh , Hisham, (2016), " The use of financial measures and nonfinancial measures to assess the performance of organizations through the Balanced Scorecard ", Journal of Economic Sciences and Management Sciences, University of Setif, Algeria, p 39.

4. Elgnaby , Maad khalef ( 2014 )," Strategic Role of Cost-Based Technology in Achieving Cost Leadership ", Tikrit Journal of Administrative and Economic Sciences, Faculty of Management and Economics, University of Tikrit, Volume seven, Number 21 .

5. Elhusiny Falah Hassan Aday ( 2014 ), " Strategic Management: Its concepts, approaches, and contemporary operations ", Amman, Dar Wael Publishing, First Edition . 
Evaluation of the influential relationship of the cost strategic analysis ...

Hussien abdelal salem

6. Said Said Abd Elfatah ( 2015 ), " Evaluation of the effectiveness of the integration of modern methods of cost management and evaluation of the tool in the rationalization of decisions in strategic management in business organizations " , The Scientific Journal of Research and Commercial Studies, Helwan University, Second Issue, first part .

7. Elshtrat , Hosny khaleel Gameel ( 2015 ), " The internal controls and their impact on the evaluation of financial performance of commercial banks: a field study " , Saleh Saleh Kamel Islamic Economics Journal, Egypt, p. 19, p. 55

8. Saleh, Sabbah fawzy ( 2014 )," Strategic Management of Cost and Its Role in Decision Making in Palestinian Service Sector Companies in the Gaza Strip: A Field Study " Master thesis , Faculty of Commerce, Accounting and Finance Department, Islamic University, Gaza .

9. Abd Elreda . Dorgham Ahmed ( 2016 ), " Introduction to Cost Measurement on the Basis of Standards with a view to Reducing Costs " , Master Thesis, Faculty of Management and Economics, University of Baghdad .

10. Abd Elazeem , Mohamed Hassan ( 2015 ) ," The Role of Accounting Information in the Activation of Strategic Management in Organizations ", Journal of Economic and Administrative Sciences, Volume 21, first issue, June.

11. Elafery, Foad Ahmed Mohamed ( 2016 ), " An integrated approach to cost management in light of competition in industrial companies " , Conference on the development of accounting in the Kingdom of Saudi Arabia, Faculty of Commerce, King Saud University.

12. Ali Ashraf Hassan Mahmoud , ( 2015 ), " Strategic cost management to maximize the value of the establishment and strengthen the competitive advantages survey study " , Master Thesis, Faculty of Commerce - Alexandria University .

13. Foda , Shawky Elsayed ( 2007 )," Proposed framework for the integration of the target cost method with the strategic cost analysis 
Evaluation of the influential relationship of the cost strategic analysis ...

Hussien abdelal salem

with a view to reducing the costs of activities through the value chain concept - a theoretical and exploratory study ", Journal of the Faculty of Commerce for Scientific Research, Faculty of Commerce, Alexandria University, First Issue, Volume forty-four, March .

14. Elkbesy, Abd Elsttar Abd El gabbar, Elkodah , Mostafa Abd Allah ( 2015 ) " The impact of financial ratios on the financial performance of public industrial companies listed on the Amman Stock Exchange ( 2005 -2011 ) " , Al-Manara Journal for Research and Studies Jordan, p.21, p.1

15. Mohamed Bstamy Mansour ( 2014 ), " Interaction between the strategic planning process of the establishment and the strategic planning process in marketing " , Al - Azhar University, Faculty of Commerce, Al - Azhar Trading Journal, Issue 25.

16. Nasef , Amany Zakaria Mostafa ( 2013 ), " An analytical study of methods and approaches to reduce the cost in light of modern environmental changes proposed framework for application in the environment of Egyptian workers ", The Scientific Journal of Research and Commercial Studies - Helwan University, Issue 4, Part II .

17. Hisham Elslwatshy and Youseef Bodola ( 2010 ), " Analysis of the competitive strength of the founder and its relation to strategic division and market division ", Algeria, 4th International Conference on Competition and Competitive Strategies for Industrial Institutions outside the hydrocarbons Sector in the Arab Countries, 8-9 November.

18. Hekal , Fawzy Mohamed ( 2014 ), The use of strategic cost analysis tools to improve the output of cost tables in order to reduce supply chain costs in industrial enterprises - field study ", Journal of Studies and Business Research, University of Banha, Issue 4.

\section{Second : foreign references :}

19.Akan, O., Allen, R.S., Helms, M.M. and Spralls, S.A. (2015), "Critical tactics for implementing Porter's generic strategies", Journal of Business Strategy, Vol. 27, No. 1. 
Evaluation of the influential relationship of the cost strategic analysis ...

Hussien abdelal salem

20.Anderson, S. W. and Dekker, H. (2015), "Strategic Cost Management in Supply Chains, Part 1: Structural Cost Management", Accounting Horizons, Vol. 23, No. 2.

21.Ansari, S., Bell, j., and Swenson, D. (2016),"A Template for Implementing Target Costing", Cost Management, Vol. 20, No. 5, Sep/Oct.

22.Atkinson, A., Kaplan, R., Ella Mae Matsumura, E. and Young, S. M. (2011), "Management Accounting: Information for that is and on The Making and Strategy Execution", 6th ed. Pearson Education, Inc.., N. J.

23.Cokins, G. and Cabusneanu, S. (2015), "Cost Drivers. Evolution and Benefits", Theoretical and Applied Economics, Vol. 17, No. 8.

24.Collin, F., Eloranta, E. and Holmström, J. (2015), "How to design the right supply chains for your customers", Supply Chain Management: An International Journal, Vol.14, No. 6, pp. 411-417.

25.Daake, D., Dawley, D. D., and Anthony, W. P. (2014), "Formal data use in strategic planning: An organizational field experimentElectronic Version", Journal of Managerial, No.16.

26.Debusk,G.K.and Debusk,C.(2014)."The Case for Lean Accounting with a concentration on Features and Characteristics Costing $(\mathrm{F} \& \mathrm{C})$ ",Cost Management,January/February.

27.Horngren ,C.,Foster,G.,and Srikant,D.,(2015),"Cost Accounting:A managerial Emphasis", $15^{\text {th }}$,Prentice Hall .

28.Jermias, J. (2015),"The relative influence of competitive intensity and business strategy on the relationship between financial leverage and performance", The British Accounting Review, Vol. 40, No. 7186.

29.Mahmoud F.M.,and Mohamed,Z.F.,(2014),"Using Attribute Based Costing (ABC11) In Customer Profitability Analysis",Buhuth Mustaqbaliya Scientific Periodical Journal,Vol.1 Issue 1.

30.Pettersson, Annelie I. (2015), "To Evaluate Cost Savings in a Supply Chain: Two Examples From Ericsson in The Telecom Industry", Operation and Supply Chain Management, Vol. 6, No. 3. 
Evaluation of the influential relationship of the cost strategic analysis ...

Hussien abdelal salem

31.Sandborn, P., Myers, J., Barron, T., and Mccarthy, M. (2014)," Using Teardown Analysis as a Vehicle to Teach Electronic Systems Manufacturing Cost Modeling", Int. Journal of Eng. Education, Vol. 25, No. 1.

32.Slagmulder, R. (2015), "Strategic Cost Management: Expanding Scope and Poundaries", Cost Management, Vol. 17, No. 1, January/ February.

33.Stein, Robert E., (2013), "Development and Implementation of Collaborative and Integrated Cost Management Tools in a Global Energy Company", AACE International Transactions.

34.Valipour, H., Birjandi, H. and Honarbakhsh, S. (2012), "The Effects of Cost Leadership Strategy and Product Differentiation Strategy on the Performance of Firms", Journal of Asian Business Strategy ،Vol. 2, No.1.

35.Walters, D. and Rainbird, M. (2004), "The demand chain as an integral component of the value chain", The Journal of Consumer Marketing, Vol. 21. 